\title{
Analisis Kualitas Terjemahan Ujaran Respon terhadap Tindak Tutur Bertanya dalam Novel Me Before You Karya Jojo Moyes
}

\author{
Ahmad Kirom ${ }^{1}$, M.R. Nababan², Djatmika ${ }^{3}$ \\ ${ }^{1}$ Master Program of Translation Studies, Postgraduate of Universitas Sebelas Maret, Surakarta, Indonesia \\ 2,3 Professor in Linguistics, Universitas Sebelas Maret, Surakarta, Indonesia \\ 1ahmadkiromm@gmail.com; 2amantaradja@gmail.com; 32djatmika@staff.uns.ac.id
}

\begin{tabular}{|c|c|}
\hline Article Info & ABSTRACT \\
\hline Article history: & $\begin{array}{l}\text { This research discusses the quality of questioning response utterances } \\
\text { found in the novel Me Before You and its translation. This aims to describe }\end{array}$ \\
\hline Submitted July 20, 2018 & (1) the types of questioning response utterances, (2) the translation \\
\hline Revised October 31, 2018 & quality of questioning response utterances based on accuracy and \\
\hline Accepted November 8, 2018 & acceptability aspects. This research is classified as a descriptive qualitative \\
\hline Published November 21, 2018 & $\begin{array}{l}\text { research which focuses on a single case. The source data of this research is } \\
\text { the novel Me Before You and the Indonesian translation version. The data }\end{array}$ \\
\hline Keywords: & $\begin{array}{l}\text { focus on questioning response utterances. The data are collected with } \\
\text { using document analysis, questionnaire and Focus Group Discussion. }\end{array}$ \\
\hline $\begin{array}{l}\text { Response, } \\
\text { Accuracy, }\end{array}$ & $\begin{array}{l}\text { Furthermore, the data is analyzed the domain, taxonomic, componential } \\
\text { analysis and cultural theme. The results of this research is the types of } \\
\text { question response utterances based on Searle's theory is variation such as }\end{array}$ \\
\hline Acceptability, & assertive, directive, commissive and expressive. Then, the quality of \\
\hline Questioning response & questioning response utterances is accurate and acceptable. \\
\hline
\end{tabular}

\section{Corresponding Author:}

Ahmad Kirom,

Master Program of Translation Studies, Postgraduate of Universitas Sebelas Maret,

Surakarta, Indonesia

Jl. Ir. Sutami 36 A, Kentingan, Surakarta, Indonesia.

Email: ahmadkiromm@gmail.com

\section{PENDAHULUAN}

Kegiatan percakapan merupakan hal yang sangat penting dalam komunikasi. Dalam melakukan percakapan salah satu hal yang sering muncul yakni tuturan pertanyaan kepada mitra tutur. Dalam kegiatan sehari-hari pertanyaan dapat digunakan untuk memperoleh informasi, memberi perintah, membuka percakapan, mengembangkan percakapan, mengontrol percakapan, dan lain-lain. Hal tersebut juga dikemukakan oleh Mahmood (2014:37) bahwa percakapan dapat berfungsi untuk (1) meminta informasi, izin, dan konfirmasi, (2) mengubah topik pembicaraan, (3) meminta penjelasan, pengulangan, pembuktian kebenaran, atau juga meminta informasi yang lebih terinci, dan (4) mengembangkan percakapan.

Respon banyak para ahli menyatakan pendapatnya, diantaranya Subandi (1982:50) mengemukakan respon dengan istilah balik (feedback) yang memiliki peranan atau pengaruh yang besar dalam menentukan baik atau tidaknya suatu komunikasi. Dengan adanya respon yang disampaikan dari komunikan kepada komunikator maka akan menetralisir kesalahan penafsiran dalam sebuah proses komunikasi. Sedangkan 
menurut Poerdawarminta (1999: 43), respon diartikan sebagai tanggapan, reaksi dan jawaban. Dari kedua penjelasan di atas dapat disimpulkan bahwa respon merupakan tanggapan atas apa yang disampaikan oleh mitra tutur kepada petutur sehingga komuikasi bisa berjalan dengan baik.

Pertanyaan, sebagai satuan kebahasaan yang digunakan oleh suatu masyarakat tertentu, dapat dikaji berdasarkan kaidah linguistik dan kaidah pragmatik. Kaidah linguistik yang dimaksud di sini adalah kaidah-kaidah yang berlaku menurut system internal bahasa tertentu, misalnya menyangkut tata bahasa dan tata bunyi. Sementara kaidah pragmatik menyangkut sisi eksternal bahasa yang mengemban suatu fungsi tertentu seperti fungsi pesan (meminta informasi, saran, konfirmasi, dan lain-lain), mengemban tatahubungan, interaksi, dan konteks penggunaan bahasa (Searle, 1969: 14).

Penerjemahan, sebagaimana yang diterangkan oleh Newmark (1988: 5) bahwa penerjemahan adalah"rendering the meaning of a text into another language in the way that the author intended the text", yaitu menerjemahkan makna suatu teks ke bahasa lain sesuai dengan yang dimaksudkan oleh penutur asli.

Senada dengan hal di atas Nida dan Taber (1982:12) mengungkapkan bahwa: "translating consists of reproducing in the receptorlanguage the closest natural equivalence of the source language message, first interms of meaning and secondly in terms of style."' Definisi dari Nida dan Taber tersebut mengemukakan bahwa gaya dan makna pada Bsa harus sepadan dengan gaya dan makna pada Bsu. Kiranya cukup jelas dari definsi yang terakhir ini bahwa penerjemahan tidak hanya mengalihkan pesan atau makna dari Bsu ke Bsa namun juga gaya bahasanya. Pernyataan tersebut diperkuat oleh (Nababan, 2003:20) yang mengatakan bahwa gaya bahasa dalam konteks penerjemahan perlu dipertimbangkan oleh penerjemah.

Penerjemahan suatu tindak tutur merupakan hal yang tidak mudah bagi seorang penerjemah karena terdapat maksud lain dari sebuah tuturan yang tidak semuanya dijelaskan dalam sebuah dialog. Senada dengan hal tersebut, Honig dalam Fawcett (dalam Singgih: 2013) yang mengatakan bahwa " However it is translated, the illocutionary force of sentence would not change". Penerjemahan yang baik tidak hanya menerjemahkan apa yang ada dalam suatu teks namun juga memperhatikan konteks kalimat yang menyertainya. Terkait dengan makna yang diterjemahkan, terkadang sebuah teks dalam Bsu tidak hanya memiliki makna secara literal atau struktural saja, tetapi ada maksud (intention) yang terkandung di dalamnya. Pengkajian suatu bahasa seperti ini bukanlah kajian pada tataran struktural karena kajian struktural sering kali menghasilkan suatu kajian yang tidak maksimal.

Example 1

Question: "Have you been a carer for long?" Response:

"Um ... I've never actually done it."

\section{Example 2}

Question: "What the hell is she supposed to do now?"

Response: "Well ... she'll just have to get another job."
Question: "Apakah anda sudah lama menjadi perawat?"

Response: "Emm... Sebenarnya saya belum pernah menjadi perawat."

Question: “Lalu..sekarang bagaimana?"

Response: “Yah...Lou kan bisa mencari pekerjaan lain." 
Dalam percakapan di atas terdapat perbedaan cara merespon dari mitra tutur kepada petutur. Selanjutnya, peneliti tertarik juga untuk mengkaji bagaimana kualitas terjemahan respon terhadap tindak tutur seperti di atas.

Diantara Penelitian terkait ilokusi masih menekankan pada jenis ilokusi lainnya salah satunya direktif (Rahmat, 2012; Kuncara, 2013; Yuliana, 2015). Di samping itu, penelitian mereka belum banyak mengeksplorasi jenis ilokusi asertif khususnya pada respon terhadap tindak tutur bertanya.

Dalam penelitian lain terkait dengan ilokusi masih menekankan bagaimana ilokusi baik ekspresif maupun direktif masih dilihat dari penggunaan oleh sekelompok orang yang meliliki budaya, dan kecakapan yang berbeda dalam menggunakan beberapa strategi (Mohsen, Jariah, 2012; Halimeh, Habib, Akbar, 2015; Sanaz ,Fariba, 2014; Omid, Zeinab, 2012). Disamping itu, dalam penelitian tersebut belum terdapat hubungan antara pragmatik dengan penerjemahan.

Dan yang terakhir, penelitian ilokusi ekspresif telah ada yang membahas tentang teknik penerjemahan dan kualitas yang digunakan dalam menerjemahkan tindak tutur diantaranya (Nuraeni, 2008, Mansur, 2014, Fitriana, 2014). Namun dalam penelitian mereka masih belum terfokus pada respon terhadap sebuah tindak tutur.

Berdasarkan hasil review di atas, peneliti memiliki kesempatan untuk melanjutkan penelitian tentang tindak tutur, khususnya pada tindak tutur asertif. Pertama, peneliti ingin mengetahui jenis respon terhadap tindak tutur bertanya berdasarkan teori Searle dan kedua, peneliti ingin mengetahui kualitas terjemahan ujaran respon terhadap tindak tutur bertanya yang dilihat dari aspek keakuratan dan keberterimaan dalam novel $\mathrm{Me}$ Before You.

\section{TEORI DAN METODOLOGI}

Penelitian ini merupakan penelitian kualitatif deskriptif dengan studi kasus terpancang dan menggunakan pendekatan pragmatik. Kemudian penelitian ini mengambil sumber data berupa novel Me Before You (sebelum mengenalmu) karya Jojo Moyes. Data yang digunakan ialah tuturan respon terhadap tindak tutur bertanya. Data dikumpulkan dengan cara analisis dokumen, kuesioner dan Focus Group Discussion. Sedangkan data yang dikumpulkan kemudian dianalisis dengan content analisis yang meliputi empat tahapan: domain, taxonomy, componensial analysis, dan finding cultural analysis.

Penilaian kualitas terjemahan pada penelitihan ini menggunakan instrument penilaian kualitas terjemahan yang dipaparkan oleh Nababan, dkk. (2012). Berikut ini sajian tabel tingkat keakuratan dan keberterimaan.

Tabel 2.1

Instrumen Penilaian Tingkat Keakuratan

\begin{tabular}{|l|c|l|}
\hline $\begin{array}{c}\text { Kategori } \\
\text { Terjemahan }\end{array}$ & Skala & \multicolumn{1}{c|}{ Parameter Kualitatif } \\
\hline Akurat & 3 & $\begin{array}{l}\text { Makna kata, istilah teknis, frasa, klausa, kalimat atau } \\
\text { teks bahasa sumber dialihkan secara akurat ke dalam } \\
\text { bahasa sasaran; sama sekali tidak terjadi distorsi } \\
\text { makna. }\end{array}$ \\
\hline
\end{tabular}




\begin{tabular}{|l|l|l|}
\hline Kurang akurat & 2 & $\begin{array}{l}\text { Sebagian besar makna kata, istilah teknis, frasa, klausa, } \\
\text { kalimat atau teks bahasa sumber dialihkan secara } \\
\text { akurat ke dalam bahasa sasaran. Namun, masih terdapat } \\
\text { distorsi makna atau terjemahan makna ganda (taksa) } \\
\text { atau makna yang dihilangkan yang mengganggu } \\
\text { keutuhan pesan. }\end{array}$ \\
\hline Tidak akurat & 1 & $\begin{array}{l}\text { Makna kata, istilah teknis, frasa, klausa, kalimat atau } \\
\text { teks bahasa sumber dialihkan secara tidak akurat ke } \\
\text { dalam bahasa sasaran atau dihilangkan. }\end{array}$ \\
\hline
\end{tabular}

Tabel 2.2

Tingkat Keberterimaan

\begin{tabular}{|l|c|l|}
\hline Kategori Terjemahan & Skala & \multicolumn{1}{|c|}{ Parameter Kualitatif } \\
\hline Berterima & 3 & $\begin{array}{l}\text { Terjemahan terasa alamiah; teknis yang } \\
\text { digunakan lazim digunakan dan akrab bagi } \\
\text { pembaca; frasa, klausa dan kalimat yang } \\
\text { digunakan sudah sesuai dengan kaidah-kaidah } \\
\text { bahasa Indonesia. }\end{array}$ \\
\hline Kurang Berterima & 2 & $\begin{array}{l}\text { Pada umumnya terjemahan sudah terasa } \\
\text { alamiah; namun ada sedikit masalah pada } \\
\text { penggunaan istilah teknis atau terjadi sedikit } \\
\text { kesalahan gramatikal. }\end{array}$ \\
\hline Tidak Berterima & 1 & $\begin{array}{l}\text { Terjemahan tidak alamiah atau terasa seperti } \\
\text { karya terjemahan ; istilah teknis yang } \\
\text { digunakan tidak lazim digunakan dan tidak } \\
\text { akrab bagi pembaca; frasa, klausa dan kalimat } \\
\text { yang digunakan tidak sesuai dengan kaidah- } \\
\text { kadah bahasa Indonesia. }\end{array}$ \\
\hline
\end{tabular}

\section{HASIL DAN PEMBAHASAN}

\section{Hasil temuan jenis ujaran respon terhadap tindak tutur bertanya.}

Setelah menganalis secara mendalam ditemukan beberapa jenis ujaran respon terhadap tindak tutur bertanya yang ada dalam novel Me Before You, kemudian diklasifikasikan menurut teori tindak tutur Searle. Peneliti menemukan empat jenis ujaran respon terhadap tindak tutur bertanya yaitu asertif, direktif, komisif dan ekspresif. Jenis ujaran respon yang paling sering muncul adalah jenis ujaran respon asertif sebanyak 116 data $(86,57 \%)$ dari 134 data penelitian. Untuk jenis ujaran respon direktif ditemukan sebanyak 13 data $(09,70 \%)$, jenis ujaran respon komisif sebanyak 2 data $(01,49 \%)$ dan jenis ujaran respon ekspresif sebanyak 3 data $(02,23 \%)$ seperti yang tertulis pada tabel berikut ini beserta penjelasannya. 
Tabel 3.1

Jenis Ujaran Respon Terhadap Tindak Tutur Bertanya

\begin{tabular}{lll}
\hline Jenis ujaran respon & Jumlah data & Presentase \\
\hline Asertif & 116 & $86,57 \%$ \\
\hline Direktif & 13 data & $09,70 \%$ \\
\hline Komisif & 2 data & $01,49 \%$ \\
\hline Ekspresif & 3 data & $02,23 \%$ \\
\hline Jumlah total & 134 & $100 \%$
\end{tabular}

a. Asertif (assertive)

Asertif adalah macam tindak tutur yang menyatakan kepercayaan penutur terhadap sesuatu, seperti menyatakan, melaporkan, menyebutkan, menunjukkan, menyimpulkan, mendeskripsikan, dan menegaskan.

Contoh:

1) Kode: 001

BSU : "What's the problem?

“Legal hitch.'

BSA : "Ada masalah apa?"

"Masalah legal"

2) Kode : 004

BSU : "Where's Mum?"

"Upstairs."

BSA : "Mum dimana?"

"Di atas."

Dari kedua contoh respon tersebut merupakan sebuah tanggapan dari teman Will, Patric dan ibu Louisa yang merupakan sebuah bentuk melaporkan dan menunjukkan. Sehingga hal tersebut merupakan bentuk dari ilokusi asertif.

\section{b. Direktif (directives)}

Direktif merupakan tindak tutur yang mengekspresikan keinginan petutur. Keinginan penutur tersebut cenderung untuk meminta petutur lain melakukan sesuatu seperti menyuruh, memohon, menuntut, menantang, memberi saran, dan memerintah.

Contoh :

1) Kode : 012

BSU : ' 'Um ... Have you ever considered joining the entertainment industry?'

“What, as in pantomime dame?'

BSA : "Emm... apa kau pernah menimbang-nimbang untuk bekerja di industri hiburan?" “Main teater, Maksudmu?"

2) Kode : 017

BSU : “I can't afford to buy a suit. What if I don't get the job?'

"You can wear mine,..."

BSA : "aku tidak mampu beli setelan. Kalau aku tidak mendapatkan pekerjaan ini, lalu gimana?"

"pakai punyaku saja,..." 
Dari kedua contoh respon tersebut merupakan sebuah tanggapan dari Louisa dan ibu Louisa yang merupakan sebuah bentuk menayakan dan menyarankan. Sehingga hal tersebut merupakan bentuk dari ilokusi direktif.

\section{c. Komisif (commissives)}

Komisif adalah jenis tindak tutur yang digunakan penutur untuk melibatkan diri mereka serta membuat komitmen terhadap suatu tindakan di masa yang akan datang. Tindakan tersebut meliputi tindakan berjanji, mengancam, menyanggupi, dan bersumpah. Contoh :

Kode : 098

BSU:-)'You'd get a tattoo?'

'If it persuaded you,

BSA:-)“ kau mau membuat tato?”

"kalau dengan cara itu aku bisa membujukmu"

Dari contoh respon tersebut merupakan sebuah respon yang berhubungan dengan masa depan yaitu pengandaian. Sehingga hal tersebut merupakan bentuk dari ilokusi komisif.

\section{d. Ekspresif (expressives)}

Ekspresif adalah jenis tindak tutur yang menyatakan tentang perasaan petutur. Subkategori tindak tutur ekspresif dapat berupa memuji, mengucapkan terima kasih, mengkritik, mengeluh, dan meminta maaf.

Contoh :

1) Kode : 014

BSU : "Would your mum like a job?"

"Funny"

BSA : "Apakah ibumu butuh pekerjaan?"

"Lucu."

2)Kode : 069

BSU : "Is there any way at all that we could get a table in here?"

"I'm really sorry,' she said."

BSA : “apakah tidak bisa diusahakan supaya kami bisa makan di sini?"

"saya benar-benar minta maaf."

Dari kedua contoh respon tersebut merupakan sebuah tanggapan dari Louisa dan pelayan restoran yang merupakan sebuah bentuk mengejek dan memnta maaf. Sehingga hal tersebut merupakan bentuk dari ilokusi ekspresif.

\section{Kualitas Terjemahan Ujaran Respon Terhadap Tindak Tutur Bertanya Dalam Novel Me Before You.}

Adapun kualitas suatu terjemahan dapat diukur berdasarkan tiga parameter penting yaitu keakuratan, keberterimaan dan keterbacaan. Dikatakan terjemahan yang ideal adalah pesan yang dialihkan akurat, berterima sesuai dengan kaidah bahasa sasaran dan mudah dipahami pembaca sasaran. Pada penelitian ini, peneliti melakukannya bersama para rater hanya menilai keakuratan dan keberterimaan. Sementara untuk teknis penilaian dilakukakan dengan memberikan kuesioner pada masing-masing rater, maka dengan begitu diharapkan mereka mampu memberikan nilai yang sesuai dengan parameter seperti yang disebutkan di atas. Proses selanjutnya adalah dilakukan FGD (Focused Group Discussion), yaitu para rater dan peneliti berdiskusi bersama untuk mencapai kesepakatan penelitian sehingga peneliti dengan mudah membuat suatu keputusan berdasarkan instrumen dan argumentasi dari masing-masing rater. 


\section{Keakuratan}

Pada penilaian keakuratan terdapat suatu hubungan kesepadanan antara teks bahasa sumber dan bahasa sasaran. Dengan kata lain, pada teks bahasa sumber harus tersampaikan secara akurat ke dalam bahasa sasaran. Untuk menilai keakuratan hasil terjemahan, langkah yang dilakukan adalah dengan menggunakan instrumen tingkat keakuratan dengan parameter yang telah dipaparkan oleh Nababan, dkk 2012.

Tabel 1. Presentasi Tingkat Keakuratan

\begin{tabular}{lcl}
\hline Tingkat Keakuratan & Jumlah & Presentase \\
\hline Akurat & 132 & $98,50 \%$ \\
\hline Kurang Akurat & 1 & $00,74 \%$ \\
\hline Tidak Akurat & 1 & $00,74 \%$ \\
\hline Jumlah $\quad 134$ & & $100 \%$
\end{tabular}

Berdasarkan tabel 1 bisa dilihat bahwa sebagian besar kata, frasa, dan kalimat yang berwujud ujaran reson terhadap tindak tutur bertanya dalam novel Me Before You (sebelum mengenalmu) adalah terjemahan yang akurat dengan jumlah sebesar $98,50 \%$ atau 132 data. Beberapa saja yang hasil terjemahannya kurang akurat, yaitu 1 data atau $00,74 \%$ dan 1 data atau $00,74 \%$ yang tidak akurat. Maka dengan demikian dapat dikatakan bahwa penelitian ujaran respon terhadap tindak tutur bertanya dalam novel $\mathrm{Me}$ Before You (sebelum mengenalmu) ini adalah terjemahan yang cenderung akurat dengan indikasi penilaian kualitas keakuratan yang tinggi. Beberapa contoh terjemahan akurat bisa dilihat pada contoh berikut ini:

Kode : $\mathbf{1 1 4}$

BSU : -) "What - what are you doing there?'

"Ssh. Don't raise your voice"

BSA : -) "Kalian... sedang apa di situ?"

Kode :078

"ssst. Pelankan suaramu.

BSU : -) "What does that mean?'

"If you'd bothered to ask me, Clark.'

BSA: -) "apa maksudnya?"

"Andai kau mau bertanya dulu padaku, Clark."

Dari kedua contoh di atas terjemahan pesan pada bahasa sumber tersampaikan secara akurat ke bahasa sasaran. Itu dibuktikan dengan tidak adanya makna yang terdistorsi pada bahasa sasaran.

\section{Contoh terjemahan tidak akurat: Kode: (080) \\ BSu : 'Are those short stories? I can't believe you noticed that.' \\ BSa : "Apakah kumpulan cepen itu?" \\ "mau bagaimana lagi."}

Dari contoh di atas terjemahan pesan pada bahasa sumber tidak tersampaikan secara akurat ke bahasa sasaran. Itu dibuktikan dengan adanya makna yang terdistorsi pada bahasa sasaran dan juga pesan yang disampaikan pada bahasa sumber tidak sepenuhnya sesuai konteks. 


\section{Keberterimaan}

Komponen ini berkaitan dengan apakah hasil terjemahan sudah diungkapkan sesuai dengan kaidah-kaidah, norma dan budaya BSa atau belum, baik dalam tataran mikro maupun makro (Nababan, 2010). Apabila keakuratan berfokus pada ketepatan penyampaian pesan, keberterimaan berfokus pada wajar atau tidaknya sebuah hasil terjemahan.

Berdasarkan penilaian tingkat keberterimaan terjemahan dari 134 data diperoleh hasil sebanyak 129 data atau sebesar 96,26\% termasuk kategori terjemahan berterima, 4 data atau sebanyak $02,98 \%$ termasuk terjemahan kurang berterima dan 1 data atau $00,74 \%$ termasuk terjemahan tidak berterima. Dengan demikian dapat disimpulkan bahwa berdasarkan kualitas keberterimaan terjemahan ujaran respon terhadap tindak tutur bertanya termasuk terjemahan yang berterima yaitu sebesar 96,26\%. Untuk lebih jelasnya dapat dilihat pada tabel berikut ini:

Tabel 2. Presentasi Tingkat Keberterimaan

\begin{tabular}{|l|c|l|}
\hline Tingkat Keberterimaan & Jumlah & Presentase \\
\hline Berterima & 129 & $96,26 \%$ \\
\hline Kurang Berterima & 4 & $02,98 \%$ \\
\hline Tidak Berterima & 1 & $00,74 \%$ \\
\hline \multicolumn{2}{|c|}{ Jumlah 134} & $100 \%$ \\
\hline
\end{tabular}

\section{Contoh terjemahan berterima:}

1. Kode : 006

BSU : -) 'Are you going somewhere?'

-)'No.'

BSA : -) “Apa kamu mau pergi?"

2. Kode : $\mathbf{1 0 4}$
-)“Tidak.”

BSU : -) “What was the best place you've ever visited?'

"In terms of what?

BSA : -) "Tempat mana yang paling asyik yang pernah kau kunjungi?"

“"Paling asyik berdasarkan apa?

Dari kedua contoh di atas terjemahan pesan pada bahasa sumber tersampaikan secara berterima ke bahasa sasaran. Itu dibuktikan ujaran respon tersebut akrab bagi pembaca dan kaidah yang digunakan sudah sesuai dengan kaidah-kaidah bahasa Indonesia.

\section{Contoh terjemahan kurang berterima dan tidak berterima:}

- Kode Data: '002

BSu : That you, love?

'Yup.'

BSa : "Kaukah itu, love?"

"Yup"

- BSu : 'Are you and Pat having some problems?'

'Mum, I -'

BSa : "Apa kau sedang ada masalah dengan Pat?"

"Mum, aku..."

Dari kedua contoh di atas terjemahan pesan pada bahasa sumber belum atau tidak tersampaikan secara berterima ke bahasa sasaran. Itu dibuktikan ujaran respon tersebut 
tidak akrab bagi pembaca dan kaidah yang digunakan tidak sesuai dengan kaidah-kaidah bahasa Indonesia.

\section{SIMPULAN}

Menurut analisis dan pembahasan yang berhubungan dengan jenis ujaran respon terhadap tindak tutur bertanya dan kualitas terjemahan ujaran respon terhadap tindak tutur bertanya dalam novel Me Before You, peneliti dapat menggaris bawahi beberapa kesimpulan akhir penelitiannya sebagai berikut:

Dari hasil analisis 134 data jenis ujaran respon terhadap tindak tutur bertanya menghasilkan empat jenis tindak tutur yaitu: asertif, direktif, komisif dan ekspresif. Ujaran respon yang mendominasi terhadap tindak tutur bertanya yaitu tindak tutur asertif.

Kualitas terjemahan ujaran respon terhadap tindak tutur bertanya dilihat dari aspek keakuratan dan keberterimaan memiliki kualitas yang baik. Itu dibuktikan dengan dari 134 data hanya 2 data yang mengindikasikan kurang akurat dan tidak akurat. Selanjutnya, berdasarkan keberterimaan hasilnya ialah dari 134 data hanya 5 data yang kurang berterima dan tidak berterima.

Dari keseluruhan data dapat ditarik benang merah bahwa hanya ilokusi asertif saja yang terdapat ketidak akuratan dan ketidak berterimaan. Sehingga bagi peneliti selanjutnya maupun penerjemah novel harus berhati-hati dalam menerjemahkan ujaran respon terhadap tindak tutur bertanya yang berjenis ilokusi asertif.

\section{DAFTAR PUSTAKA}

Chafe, W.L. (1970). Meaning and the sructure of language. Chicago: The University of Chicago Press.

Chafe, W.L. (1976). "Giveness, contrastiveness, definitness, subject, topics, and point of view". Dalam Charles N Li.(ed.) Subject and Topic. New York: Academic Press.

Comrie, B. (1981). Language universal and linguistics typology (Syntax and Morphology). Oxford: Basil Blackwell.

Comrie, B. (1987). "Grammatical Relations, Semantic Roles and Topic-Comment Structure in A New Guinea Highland Language: Harway". Dalam Ross Steele dan Terry Threadgold (ed.) Language Topics: Essays in Honour of Michael Halliday Volume 1. Amsterdam/Philadelphia: John Benjamins Publishing Company.

Crystal, D. (1987). The cambridge encyclopedia of language. Cambridge: Cambridge University Press.

Duzzak, A. (1990). "The Nominative and The Dative Prespective in The Topic-Comment in English and Polish". Dalam Jacek fisiak (ed.) Further insights into Contrastive Analysis. Amsterdam/Philadelphia: John Benjamins Publishing.

Fitriana, I. (2014). Analisis teknik dan kualitas terjemahan tindak tutur ekspresif dalam Novel Stealing Home (Hati Yang Terenggut) karya Sherryl Woods. Tesis. Universitas Sebelas Maret Surakarta.

Ghanbaria, H. et al. (2015). Investigating apology strategy among kurdish bilinguals: a case study in ilam. Elsevier Ltd. Procedia - Social and Behavioral Sciences $204-210$. Science Direct 
Kuncara, S. D. (2013). Analisis terjemahan tindak tutur direktif pada novel the godfather dan tejemahannya dalam bahasa Indonesia. Tesis. Universitas Sebelas Maret Surakarta.

Levinson, S. C. (1983). Pragmatics. London: Cambridge University Press.

Mahmood, K. R. (2014). A pragmatic analysis of yes/no questions in English request speech act strategies. Elsevier Ltd. Procedia - Social and Behavioral Sciences 46 (2012) 678 - 685.Science Direct.

Mansur, A.A. (2014). Kualitas terjemahan bentuk mitigasi pada tindak tutur memerintah (commanding) dalam dua seri novel Harry Potter. Tesis. Universitas Sebelas Maret Surakarta.

Nababan M. R., et al. (2012). Pengembangan model penilaian kualitas terjemahan. Kajian Linguistik dan Sastra, Vol. 24, No. 1, Juni 2012: 39-57

Nababan, M. R. (2003). Aspek teori penerjemahan dan pengalihbahasaan. Yogyakarta: Pustaka Pelajar.

Nababan, M. R. (2010). Pengembangan model penilaian kualitas terjemahan. Ringkasan hasil penelitian UNIKOM Tahun II 2010. Universitas Sebelas Maret Surakarta

Nababan, M.R. (2008). Kompetensi penerjemahan dan dampaknya pada kualitas terjemahan. Sidang senat terbuka. Pidato Pengukuhan Guru Besar Penerjemahan. Universitas Sebelas Maret Surakarta.

Newmark. (1988). A textbook of translation. Singapore: Prentice Hall

Nuraeni, A. (2008). Perbandingan terjemahan "tindak tutur mengeluh" dalam film. bad boys ii yang ditayangkan di stasiun televisi dan VCD. Tesis.Universitas Sebelas Maret Surakarta

Poerdawarminta. (1999). Psikologi komunikasi. Jakarta. UT.

Rastegara, et al. (2014). Iranian EFL Learners' Proficiency Levels and Their Use ofApology Strategies. Elsevier Ltd. Procedia - Social and Behavioral Sciences 1535 1540.Reference to Press Conferences. Elsevier Ltd. Procedia - Social and Behavioral Sciences 136 (2014) $36-40$.

Subandi, A. (1982). Psikologi Sosial. Jakarta. BulanBintang

Tabatabaeia, et al. (2012). Transfer of requestive speech act from L1 to L2 in Iranian EFL learners. Elsevier Ltd. Procedia - Social and Behavioral Sciences 70 ( 2013 ) 239 244.Science Direct.

Wisudawanto, R. (2012). Analisis terjemahan tuturan karakter Spongebob dalam komik amazing journey dan terjemahannya dalam bahasa Indonesia. Tesis.Universitas Sebelas Maret Surakarta.

Yasamia, et al. (2014). The use of thanking strategies among Iranian EFL learners of different proficiency levels. Elsevier Ltd. Procedia - Social and Behavioral Sciences 98 ( 2014 ) 1926 - 1930. Science Direct

Yuliana, R. (2015). Analisis tidak tutur direktif dalam Dora the explorer: super babies' dream adventure dalam terjemahannya petualangan mimpi bayi super. "Seminar prasastill"Kajian Pragmatik Dalam Berbagai Bidang.

Yusefia, et al. (2015). A pragmatic analysis of thanking strategies among kurdish speakers of ilam based on gender and age. Elsevier Ltd. Procedia - Social and Behavioral Sciences 199 ( 2015 ) 211 - 217. Science Direct. 